\title{
What's Behind a Name? Origins and Meaning of Some of the Recurrent Characters in Terry Pratchett's Discworld
}

\begin{abstract}
Nominative symbolism in fantasy is a tool to attribute certain traits to literary characters and thus to convey meaning which enriches the readers' comprehension of the fictitious personality. Proper names in the English naming tradition are not generally seen as means of alluding to the character of a person, yet they have sometimes been chosen purposefully by writers so as to reveal the idea that a symbolic name tries to convey. The paper therefore aims at investigating the origin and author's intended meaning behind the names of some recurrent literary characters in Terry Pratchett's Discworld series from the viewpoint of their structure and the allusions they evoke in the reader's imagination. The analysis includes five names presenting three different structures: neologisms based on syntactic composition, imitations of borrowed structures that are foreign to the English model of naming, and typical English naming models where name symbolism is due to the lexical choice of the components in the name.
\end{abstract}

Keywords: onomastics, literary onomastics, proper names, allusiveness, literary names, charactonyms

\section{Kaj se skriva za imenom? Izvori in pomeni imen nekaterih likov v seriji romanov Plošča Terryja Pratchetta}

\section{POVZETEK}

V fantazijskem žanru je nominativni simbolizem orodje za pripisovanje določenih lastnosti književnim likom, simbolni pomeni pa bogatijo bralsko dojemanje fiktivnih likov. V angleški poimenovalni tradiciji lastna imena praviloma ne služijo prikazu osebnih lastnosti, jih pa pisci tu in tam načrtno izberejo prav zaradi njihovih simbolnih pomenov. $\mathrm{V}$ prispevku raziskujem izvor in namen imen likov, ki se pojavljajo v Pratchettovi seriji romanov Plošča $s$ stališča njihove strukture in asociacij, ki jih sprožijo v domišljiji bralstva. Analiza vsebuje pet imen, ki predstavljajo tri različne strukture, in sicer neologizme, ki temeljijo na sintaktični kompoziciji; imitacije izposojenih struktur, ki so tuje angleškemu modelu poimenovanja; in tipične angleške poimenovalne modele, kjer se simbolni pomen imena ustvarja z leksikalnim izborom sestavin imena.

Ključne besede: onomastika, književna onomastika, lastna imena, nanašanje, književna imena, karaktonimi 


\section{Introduction}

Names in literature, referred to as "charactonyms" (Fowler 2012, 187) or literary names, often prove to be the result of research undertaken with the purpose of devising a name with the most appropriate meaning it is intended to possess and convey. Depending on the genre, charactonyms can serve various functions and reveal different ideas. Naming in children's literature, for instance, is usually closely related to the physical features the personages possess, thus easily reaching the target audience. In adult literature, however, finding the significance of a proper name is a far more challenging and difficult task. This is by no means a hindrance, since it makes the literary name a more powerful "weapon" in the hands of the author and inevitably leads to a stronger emotional and more thorough understanding of a piece of writing by the reader.

A genre where one can truly take pleasure in reading and deciphering meaningful names is fantasy literature. There, charactonyms are not only symbolic, they are also quite interesting from a linguistic point of view, since they present newly coined phonological, morphological and syntactic structures, which make it possible for the name to suggest interpretative features attributed to a character. Following Vlahov and Florin, in order a name to serve a meaningful function it has to possess certain characteristics, the first one being allusiveness, i.e. the proper name should allude to a real folklore, literary, or proverbial character. Another characteristic proper names should possess so that they are seen as symbolic or meaningful is the presence of a phonetic form that can promote a certain effect of the name itself (Vlahov and Florin 1990, 233). Therefore, this paper aims at finding the etymology of five of the recurrent characters in the Discworld series written by Terry Pratchett, the author of many best-selling fantasy novels. Following the analysis of the origin of names, different structures of names will be discussed - neologisms which are based on "syntactic compositions" (Boyadzhieva 2007, 240); names, which are imitations of borrowed structures, foreign for the English naming tradition; and names which follow the typical English naming models but the name symbolism is seen in the lexical choice of the components of the name.

\section{Theory and Analysis}

\subsection{Preliminary Remarks}

Names can be perceived as an interdisciplinary phenomenon, as they are primarily relevant to onomastics, given the etymology and distribution of a certain anthroponym over a certain region at a given time; yet possessing subsidiary connection to the fields of morphology and syntax, semantics, sociolinguistics and theory of translation, where the symbolism of names is to be sought. Literary names to some extent resemble ordinary proper names, yet are used in some cases by the author to attach certain features to the character of the bearer, thus making the image of a literary figure more prominent and easily perceived by the reader. As Fowler suggests,

the habit of finding moral meanings in all sorts of names led to their being regarded as ideals of behaviour, especially for the bearer of the name. One's name was to be lived up to, and valued because of embodying reputation: it might therefore be of ultimate importance. (Fowler 2012, 15) 
Ragussis gives an interesting interpretation of what names are with regard to how they relate to etymology. He claims that

each name comes into being in the present, with a discrete significance. In contrast, etymology seeks not to strip a name of its associations, but to restore to the name its many historical associations, and thereby to bring into being all the names hidden within the name under investigation. (Ragussis 1987, 178)

Van Langendonck $(2007,22)$ further suggests that proper names possess lexical, associative and emotive meaning, which lies in the core of nominative symbolism.

Gibka (2015) quotes Aleksander Wilkoń who proposed a typology of the functions of literary proper names including "one primary function - denoting particular people and places - and five secondary functions: the localizing, sociological, allusive, expressive and semantic." When translation is concerned, Boyadzhieva $(2017,17)$ adds that: "special pre-translating research is essential for the professional translator aiming at retaining the message contained in the original name as far as possible." Boyadzhieva's approach is not only relevant to translation, as it encompasses the whole process of identification and understanding of a certain literary name.

Names of literary characters, also called "speaking” names (Boyadzhieva 2017; ManovaGeorgieva 2016, 2017), depending on the genre, can appear meaningful and thus have a revealing symbolism. Examples of "speaking" names can be Little Red Riding Hood (after the fairy tale of the same name); Cruella De Vil, the villainess from 101 Dalmatians; and Pinocchio (from Italian "a pine tree"), the wooden boy created by the Italian writer Carlo Colody.

When talking about adult literature, a point is to be made that not all proper names in a piece of writing are considered "speaking" ones. In reality, only a small percentage of all names of characters in a literary work appear meaningful. However, the Discworld series is an exception.

Sir Terence David John Pratchett (1948-2015), better known as Terry Pratchett, an English author of fantasy novels and comical books as well as novels for children, purposefully chose specific names for his characters so as to complete the image the character conveys, to elicit certain traits they possess, or to parody the picture of the character in the reader mind.

These preliminary remarks close with the following from Lutterer $(1982,63)$, which should be borne in mind throughout this paper:

firstly, the author is simply the person who wrote the book, the author's situational context refers to the circumstances accompanying the process of writing and especially of inventing names. The name is the linguistic sign given to an entity as its label, and the object is the entity.

\subsection{Corpus and Methodology}

As already mentioned, the current paper is aimed at the analysis of five recurrent characters in the Discworld series, namely Visit-the-Infidel-with-Explanatory-Pamphlets, Cut-Me-Own- 
Throat Dibbler, Leonard of Quirm, Cheery Littlebottom and Ponder Stibbons, where the focus is on the nominative symbolism concealed in all of them. The analysis includes the etymology of the first and family names of the personages, as well as the peculiarities in their form. The names are classified in accordance with their difference in structure from a linguistic point of view, and hence are divided into three categories. The first group presents names appearing as neologisms based on compound syntactic structures. The second category is the one showing a typical English naming pattern, whereby the nominative symbolism lies in the lexical meaning of the proper name of the personage. The last one encompasses those names the naming pattern of which presents borrowed structures.

\subsection{Analysis}

The Discworld series comprise a set of forty-one novels, the first twenty-six of which were published within over 18 years. The series starts with The Colour of Magic, written in 1983, where the basic plot is established and then develops between Ankh-Morpork and the hub. It continues in time and settings to include the Unseen University, Death's Domain, the Kingdom of Lancre, as well as various other places. After 2001 several short stories, science books together with reference works appeared, although only loosely related to the Discworld. The novels are usually not divided into chapters, and there are certain main characters that continuously appear throughout the storyline (Death, Granny Weatherwax, Nanny Ogg, Cut-Me-Own-Throat Dibbler, Lord Havelock Vetinary, etc.). The books parody J.R.R. Tolkien, Charles Dickens, William Shakespeare, and others on various occasions (Butler 2001).

In relation to the characters of the Discworld, what has to be taken into consideration is the variety of names and name structures Pratchett uses. As the number of personages is too large, the current paper focuses on the basic naming structures that are related to five characters.

\subsubsection{Neologisms Based on a Specific Syntactic Structure}

Cut-Me-Own-Throat Dibbler, his full name being Claude Maximillian Overton Transpire Dibbler, is a character that first appears in Guards! Guards! (1989) as s seller of goods and later in Moving Pictures (1990), Reaper Man (1991), Witches Abroad (1991), Men at Arms (1993), and other titles. He is a businessman mainly seeking to profit by selling his Sausage inna bun (a kind of a hotdog). Since his disgusting sausages make people who eat them feel sick, he continuously tries to improve his business either by changing the ingredients of the sausages or by lowering their price. In Witches Abroad he is introduced under the name Grand Master Lobsang Dibbler giving "fong shooey" advice as well as martial arts lessons. ${ }^{1}$ In Soul Music he becomes the first character in the Discworld to become the manager of a music band. CutMe-Own-Throat Dibbler even finds employment as the writer of the Discworld version of the National Enquirer, a weekly tabloid where he entertains readers with sensational stories for the Ankh Morpork Times newspaper.

Discworld Wiki, s.v. "Cut-Me-Own-Throat Dibbler," accessed August 23, 2019, https://discworld.fandom.com/wiki/ Cut-Me-Own-Throat_Dibbler. 
Concerning the etymology and meaning of his name, Dibbler's first name is a shortened form of his own claim: "Selling this at such a low price that it's cutting me own throat" which is related to the verbal manipulation by means of which he can successfully sell his products. The whole first name of the personage is in fact a syntactic composition of an imperative clause where the different parts of the clause are hyphenated. The structure of the collocation leads to the conclusion that it is Cut-Me-Own-Throat that is the personage's first name and Dibbler his family name.

The full name of the character Claude Maximillian Overton Transpire Dibbler provokes further thinking with regard to its origin. The first component of the compound name is clearly of French origin. Claude is a male or female form of Claudius, common since the 7th century, later imported to Britain in the 16th century by the Hamilton family, bearing the meaning "lame". ${ }^{2}$ Maximillian is also a male first name, found in English, German, Swedish, Norwegian and Danish in various forms. The name Maximillian is derived from Maximus, having first appeared in the 3rd century as the name of a saint and martyr. The second forename of Dibbler means "greatest".

Overton is a family name associated most often with Joseph P. Overton. It is usually found in the collocation the Overton Window, alluding to a political novel by Glenn Beck released in 2010 , or, more probably, to the term itself, presenting policies which are politically acceptable for the mainstream population at a certain time. The next element of the name, transpire, means to become known, and Dibbler, occupying the surname position, can be related to the slang word dibs meaning "money", or "a right to have or get something from someone, or to use something", ${ }^{4}$ as alluding to the mercantile aspirations of all the characters that share the name. However, there may be another explanation, as according to Wikipedia dibbler is the common name for Parantechinus apicalis, an endangered species of marsupial. $\mathrm{Me}$, respectively, is the non-standard form of $M y$, which might refer to a non-elite belonging of the personage.

There are several Dibblers living in different regions of Discworld who appear in the series. Each of them is spelled in a different way following the same syntactic pattern, yet bringing different cultural allusions to the reader. The Omnian (alluding to the Middle East) D'blah's name is Cut-Me-Own-Hand-Off (in Small Gods), and the Auriental (alluding to the Far East) Dibhala's is May-I-Disembowel-Meself-Honourably (in Interesting Times). Similarly to Ankh Morpork's Cut-Me-Own-Throat, these names can function alone. Thus, the hyphenated syntactic compositions fulfil an identifying function by referring to unique entities, meaning that they serve as given names, while Dibbler (and its phonetic variants D'blah and Dibhala) refer to the family of the Dibblers and are to be analysed as surnames (Boyadzhieva 2017).

Visit-the-Infidel-with-Explanatory-Pamphlets, sometimes referred to as Visit-the-Ungodlywith-Explanatory-Pamphlets, is an Omnian, among the several human members of Ankh-

Online Etymology Dictionary, s.v. "Claudius," accessed July 15, 2019, https://www.etymonline.com/word/claudius. Behind the Name, s.v. "Maximilian", accessed July 15, 2019, https:/www.behindthename.com/name/maximilian. Cambridge Dictionary, s.v. "dibs," accessed August 23, 2019, https://dictionary.cambridge.org/dictionary/english/ dibs. 
Morpork, who first appears in Feet of Clay (1996) and later in Hogfather (1997) as well as Jingo (1997), The Fifth Elephant (1999) and Thud! (2005). His appearance is positive, smiling and optimistic. Pictured as a young man of foreign origin, holding a leaflet, he talks to people, enters pubs and various other places in order to express and defend his religious ideas. He is a preacher, not believing or trusting other religions different from the cult of Om, suggesting that all other religions are "misguided" and "false". ${ }^{5}$ Although he has a rather long name, he is often referred to as just "Visit", which is in fact his main occupation - going from house to house, infuriating his neighbours and fellow citizens with his stories and pamphlets. Visit-the-Infidel-with-Explanatory-Pamphlets is also known by the nickname of Washpot.

Structurally, the name of Visit-the-Infidel-with-Explanatory-Pamphlets appears to be a personal first name. There is no part of the entity which points to possessing the characteristics of a family name for two reasons. First, not even one part of the name is separated from the main entity, i.e. all parts are hyphenated, which is typical for the so-called syntactic compositions. Second, no noun is post-positioned with regard to the hyphenated structure of the name. If one looks at the name and concludes that it is only a compound first name, then an imperative clause can be elicited. Semantically, the whole name can be realised as showing the actions of Constable Visit in several aspects. The Merriam-Webster Dictionary gives a definition of infidel as "an unbeliever with respect to a particular religion; one who acknowledges no religious belief". 6 The definite article preceding the count singular noun infidel suggests a collective noun, or else referring to a group of people possessing the characteristics of unbelievers. The common noun infidel is followed by an adverbial modifier of accompanying circumstances introduced by the preposition with. The whole first name semantically follows a classical syntactic structure, yet it is seen as a neologism, since names in the English naming system are not traditionally constructed as clauses. This evokes an effect of parody with the creation of the personage.

Considering the nickname given to Constable Visit, washpot can be regarded as "a large metal pot used outdoors for boiling clothes over an open fire". ${ }^{7}$ Yet it can refer to the biblical phrase "Moab is my wash pot, over Edom will I cast out my shoe: Philistia, triumph will become on me." $\mathrm{A}$ washpot was a type of small bath in which people washed their feet for religious reasons. In relation to Visit, he might be considered "the bath" where the unbelievers wash and change their views towards religion in general and Om in particular.

\subsubsection{Typical English Naming with Specific Lexical Choice by the Author}

Cheery Littlebottom is a dwarf, introduced in Feet of Clay (1996) and appearing in three more books (Jingo (1997), The Fifth Elephant (1999) and Thud! (2005)). Cheery has a beard, wears boots and an iron helmet. Despite her dwarfish look - being plump, bearded, and short, wearing layers of clothing - she seems to be different from other common dwarfs in the aspect

\footnotetext{
Discworld Wiki, s.v. "Visit-The-Infidel-With-Explanatory-Pamphlets," accessed August 24, 2019, https://discworld. fandom.com/wiki/Visit-The-Infidel-With-Explanatory-Pamphlets.

Merriam-Webster, s.v. "infidel," accessed August 26, 2019, https://www.merriam-webster.com/dictionary/infidel.

Merriam-Webster, s.v. "washpot," accessed August 26, 2019, https://www.merriam-webster.com/dictionary/washpot.

8 Biblehub, s.v. "Psalm 60:8," accessed August 27, 2019, https://biblehub.com/commentaries/psalms/60-8.htm.
} 
that she dislikes beer and gold, and is even the first female dwarf member of the Watch in AnkhMorpork. The public demonstration of her feminine nature causes a Cultural Revolution in Dwarfdom, which starts with the introduction of the pronouns she and her in Dwarfish. This causes notable unrest among the dwarf population of Discworld, which is otherwise genderblind. The immediate effect of her appearance is that many young dwarves start wearing makeup and high-heeled boots, and also stop hiding the issue of belonging to a third sex.

In relation to the name, the forename Cheery phonologically follows Walt Disney's pattern of creating classical dwarfish names such as Sleepy, Dopey, Grumpy etc. But it does not derive from the English root cheer as she herself prefers the pronunciation /' $\mathrm{t} \int \mathrm{eri} /$ to /' $\mathrm{t} \mathrm{fi}: \mathrm{ri} /$.

According to Pratchett's official webpage, Cheery is "apparently a literal translation" of her original dwarfish name which is Sh'rtazs. Yet, there might be another equally acceptable interpretation, namely that the word Shrtazs is a Dwarfish family name, the English pronunciation of which is very close to shortarse, literally translated as Littlebottom, holding a humorous reference either to her race or her sex, or both.

Another possibility is that her name derives from a well-known British nonsense phrase Cheery Bum which is a mispronunciation of the title of an Italian song "Ciribiribin" as Cheery Bum, with the original recorded by Grace Moore in 1934 and gaining popularity through such singers as Frank Sinatra. This explanation is also acceptable because it holds the semantic relation between bum, the colloquial word for bottom, and the head noun in the compound Littlebottom, which is in fact Cheery's family name.

There is yet another relation Cheery's name (pronounced / $\mathrm{t}$ feri/) may allude to, one that is based on a historical fact. In March 1833 Lieutenant General James Thomas Brunedell, 7th Earl of Cardigan was allowed the command of the 11th Light Dragoons that later became famous as the 11th Hussars. As he wished his officers to be as aristocratic, flamboyant and stylish as he was himself, he spent $£ 10,000$ on the regiment so the 11 th Hussars soon became the smartest cavalry regiment in the service. Because of the cherry-red colour and tightness of their overalls, they became known as the "cherry-bums" where bum is a euphemism of bottom. The term cherry bum army is also recorded in A Dictionary of Slang, Jargon and Cant (Barrère and Leland [1889] 1967).

There is also a direct allusion with Cheery's striving for elegance and desire to stand out from the regular members of the Watch. Very often her taste for unusual attire causes embarrassing episodes, such as wearing a miniskirt during an interrogation as well as the use of make-up and nail polish. At the end of Feet of Clay she even hopes to receive her friend Angua's dresses after she decides to leave the Watch and join the werewolves back in Überwald, something unheard of in the world of the dwarves.

Littlebottom is Cheery's family name, and thus she declares that this is the name her father and her family take pride in. Morphologically the surname Littlebottom is a compound noun and lexically it is a coinage. Structurally, its postposition infers its primary function of a nickname, showing the physical characteristics of the bearer. The postposition of the family name also leads to the conclusion that it was originally a nickname that started to be used 
as a family name. Weekley (1914), Van Langendonck (2007) as well as Withycombe (1947) suggest that family names are to be categorized as inherited, showing location or place of living, profession, and last but not least, having been derived from nicknames which show the physical or psychological characteristics of the bearer. According to Weekley $(1914,2)$, "every surname must be (i) personal, from the sire or ancestor, (ii) local, from the place of residence, (iii) occupative, from trade or office, (iv) a nickname, from bodily attributes, character, etc."

All of this leads to the conclusion that Cheery is the forename and Littlebottom is a family name derived from a nickname related to physical appearance.

Ponder Stibbons, a male human who at first sight looks similar to Harry Potter, is a student wizard who is first introduced in Moving Pictures (1990). He is later seen in Lords and Ladies (1992) as a member of the faculty, and in The Last Continent (1998), where he is trapped together with Mustrum Ridcully, the Bursar and Librarian on a desert island. He is also appointed as the creator of Hex (a somewhat magical computer full of mice and ants), and appears to be far more intelligent than even Terry Pratchett might have imagined him to be. ${ }^{9}$ He advances to become the Head of Inadvisably Applied Magic, a lecturer as well as reader in invisible writings, among several other positions, which makes him capable of dealing with all the work in a faculty. The strange circumstances under which he graduated are related to completing a test which was meant for an absent student, Victor Tugelbend, and which in reality contained only one question. Although he resembles Harry Potter he cannot be seen as a parody of the famous boy wizard, since the first Harry Potter book was published seven years after Ponder's first appearance.

With regard to his forename, Ponder seems a typically male name judging by its ending. It resembles Rodger, Peter, etc. Semantically, Cambridge Dictionary defines the verb ponder as "to think carefully about something, especially for a noticeable length of time". Concerning its origin, the first account of the word ponder goes back to the early 14th century, meaning "to estimate the worth of, to appraise", the Latin root of the word ponderare "ponder, consider, reflect", literally "to weigh", from pondus (genitive ponderis) "weight", from the stem of pendere "to hang, cause to hang; weigh". ${ }^{10}$ The definition of the forename fully reflects the profile of the personage, as he is presented as clever, somewhat strange, yet one who can always get a job done at the Unseen University.

As far as the family name Stibbons is concerned, its etymology and literal meaning is quite unclear. First, one can conclude that Stibbons is in fact a family name because it is postpositioned with regard to the forename of the personage. Second, the orthographic structure of the name also points to the fact that this is the case. Family names ending in $-s$ were popular in the late 13th century in Wales, and this gives grounds to assume that the family name Stibbons might be of Welsh origin.

Another interpretation of the family name related to the $-s$ morpheme is that it can be seen as a flexion for plurality, leading to the assumption that the family name might refer to the people

\footnotetext{
$9 \quad$ Discworld Wiki, s.v. "Ponder Stibbons," accessed August 27, 2019, https://discworld.fandom.com/wiki/Ponder_ Stibbons.

10 Cambridge Dictionary, s.v. "ponder," accessed August 27, 2019, https:/dictionary.cambridge.org/dictionary/english/ ponder.
} 
of Stibbon. The same $-s$ can also be interpreted as a marker for the genitive case to express possession, i.e. family affiliation (Netsova 2016, 63). All of the above-stated hypotheses about the family name Stibbons seem probable, yet the most credible one for me is that the $-s$ morpheme shows family affiliation.

Etymologically speaking, the family name Stibbon can be identified in the Old Norse, Styrbjörn; the Danish, Stybe; the German, Stibane; a personal name. ${ }^{11}$ A variation of the name can also be recognised in the Scandinavian Styrbjörn the Strong (the name of a prince who died circa 985 AD). The son of the Swedish King Olof, he was believed to have been given the name Björn, as for Styr-, it was added after his growing up as an epithet meaning restless, controversially forceful and violent. ${ }^{12}$ As a result, it can be concluded that the family name of Ponder Stibbons orthographically and phonetically resembles the contemporary English adjective stubborn. The Cambridge Advanced Learner's Dictionary gives the meaning of stubborn as "a stubborn person is determined to do what he or she wants and refuses to do anything else; things that are stubborn are difficult to move, change, or deal with". ${ }^{13}$ This meaning completes the image of the personage - a bit lazy at first, however, having grown to be persistent and thoughtful, yet strange for some of his acquaintances.

\subsubsection{Imitations of Borrowed Structures}

Leonard of Quirm is a representative of the human race, who appears in several parts of the Discworld series, among which are Wyrd Sisters (1988), Men at Arms (1993), Jingo (1997), and The Fifth Elephant (1999). Although his age is unknown, his image suggests a genius of elderly nature with a balding forehead and white hair. His outer appearance fully corresponds to the deeds he is occupied with. As his name suggests, he is originally from Quirm, yet he moves to Ankh-Morpork at some point in time, and upon being introduced on the Disc is a permanent guest-companion of Lord Havelock Vetinary, the Patrician. Ironically enough, the Patrician firstly plots to murder him Leonard yet later finds a good listener and advisor, so Vetinary just keeps him "imprisoned" in his own castle. "Imprisoned" might not serve the best word to express the way Leonard feels at the Patrician's palace, as he finds great peace there. The only traps around this so-called prison are the ones he has constructed himself.

Apart from being an engineer, obvious in The Fifth Elephant where he constructs a device with a destructive nature, he also invents other creations such as the Going-Under-TheWater-Safely-Device, the Very Fast Coffee Machine as well as the Engine for the Neutralising of Information by the Generation of Miasmic Alphabets. Moreover, his talent for inventing machines does not stop with this. He finds special names for them, varying from the abovestated inventions to the Gonne, a portable firearm, which, Leonard, being left-handed and writing backwards, initially writes as ENNOGEHT. "The names Mr. Doodle and Detritus are given to Leonard da Quirm because of his handwriting and terrible ineptitude in naming his inventions" (Gibka 2015, 56).

\footnotetext{
Forebears, s.v. "stibbon," accessed August 28, 2019, https://forebears.io/surnames/stibbon.

Nordic Names, s.v. "Styrbiǫrn," accessed August 28, 2019, https://www.nordicnames.de/wiki/Styrbi\%C7\%ABrn.

3 Cambridge Dictionary, s.v. "stubborn," accessed August 28, 2019, https:/dictionary.cambridge.org/dictionary/ english/stubborn.
} 
Together with his creative mind, Leonard also shows a talent for painting. The name of the personage follows the original name structure in Italian, alluding to the great painter Leonardo da Vinci. This allusion is further substantiated with the relationship between Vetinary and Leonard of Quirm and the one between da Vinci and the families of the Medici and Borgias, who commissioned several projects from the painter, as also discussed in Boyadzhieva and Kalapsazova (forthcoming).

One of da Quirm's most famous paintings is Mona Ogg, a parody of da Vinci's Mona Lisa. The discrete, magnificent smile of Mona Lisa is in this substituted for a grin on the face of Mona Ogg in Men at Arms.

Concerning his name, the forename of Leonard can be found in English, Dutch, German, and French. Its pronunciation is LEHN-ord (English), LAY-o-nabrt (Dutch), and LEH-onart (German). Semantically, the forename bears the meaning of "as brave as a lion", having derived from the Germanic elements lewo (from Latin) and hard (brave, hardy). Variations of the name close to the personage of interest here are Léonard (French), Leonardo (Italian), Leonardo (Portuguese) and Leonardo (Spanish). ${ }^{14}$ Taking into consideration his occupation and his paintings, Mona Ogg (Mona Lisa) and Woman Holding Ferret (Lady with an Ermine), one can easily conclude that he is a parody of Leonardo da Vinci. The phonological form of his name also alludes to the Italian artist. Moreover, at times he is just called Leonardo, or $d a$ Quirm, when his first name is skipped.

Leonard's interests in engineering and technology also allude to another prominent historical figure, namely Nikola Tesla, an inventor and engineer, known for his creations related to electricity as well as for giving names to his inventions, yet there is no resemblance with regard to the name of the inventor and that of the character.

\section{Conclusion}

Literary names, also called charactonyms, are a specific part of the camouflage of a writer. When used purposefully and wisely, they succeed to convey the full idea of the image an author has aimed at presenting to the reader. Gibka (2015) refers to authors as "middlemen". They are the ones who create the images, name them, and if the name is a successful choice they are able to draw the nuances of the character of the personage. With a prolific and sophisticated author such as Terry Pratchett, the invention of symbolic names involves a lot of forethought and analysis, allusive thinking as well as broad encyclopaedic knowledge and linguistic creativity.

The names analysed in the paper are complex semantically and structurally, as well as thought-provoking with regard to choices made by the author. Although challenging, it is not impossible to elicit categories of symbolic names in the Discworld series. The names of interest fall into three categories based on their syntactic structure, etymology and semantic meaning.

14 Behind the Name, s.v. "Leonard," accessed August 28, 2019, https://www.behindthename.com/name/leonard. 
The category most conducive to analysis is that of borrowed structures. A consideration of the occupation and interests of Leonard of Quirm leads to the allusion to the famous inventor and painter. The structural resemblance of the Italian naming pattern makes the name recognizable and thus allusive.

The category related to the typical English naming system, yet with concealed lexical symbolism, is usually the most challenging, since a certain character might exhibit the qualities that their name suggests or they might parody them. In the case of the dwarf Cheery Littlebottom, the symbolic nature is clear as it is related to the physical characteristics of the bearer, whereas with the other representative of the category, Ponder Stibbons, the literary name carries a far more complicated message.

The most interesting category from a syntactic point of view is that of syntactic compositions, the forenames of which are hyphenated imperative clauses. This category is relatively new in literary onomastics in general terms, yet not uncommon in fantasy. The concealed meaning of these structures gives liberty to the reader to perceive the character of a personage in a more visible and clearer way.

Given the phonological, lexical and syntactic analysis presented in this study, the Discworld series provides the researcher with a great number of literary names and interesting lexical or syntactic structures, and therefore this paper addresses only a small part of the universe of charactonyms invented by Terry Pratchett.

\section{References}

Barrère, Albert Marie Victor, and Charley Godfrey Leland, eds. (1889) 1967. A Dictionary of Slang, Jargon and Cant, Embracing English, American, and Anglo-Indian Slang, Pidgin English, Tinker's Jargon, and Other Irregular Phraseology. Detroit: The Ballantyne Press. https://archive.org/details /adictionaryslan00lelagoog.

Beck, Glenn. 2010. The Overton Window. New York: Threshold Editions / Mercury Radio Arts.

Boyadhzieva, Ellie. 2007. "Reflections on a New Word-Formation Pattern in Bulgarian Newspaper Language." In Za choveka i ezika, edited by Alexandra Bagasheva, 232-44. Sofia: Sofia, St. Kliment Ohridski University Publishing House.

—. 2017. "Name Symbolism and the Bulgarian Translations of Terry Pratchett's Discworld Characters." International Scientific and Practical Conference "WORLD SCIENCE” No. 8 (24), Vol. 2, August 2017: 16-31.

Boyadzhieva, Ellie, and Elena Kalapsazova. Forthcoming. "The Hermeneutic Power of Names.” Contemporary Literature.

Butler, Andrew. 2001. Terry Pratchett. Harpenden, UK: Pocket Essentials.

Fowler, Alastair. 2012. Literary Names: Personal Names in English Literature. Oxford: Oxford University Press.

Gibka, Martyna Katarzyna. 2015. "The Functions of Proper Names in the Literary Work of Art.” Symbolae Europaeae 8: 79-90.

Lutterer, Ivan. 1982. "Onymical Mistake in the Naming Process." In Proceedings of the XIIIth International Congress of Onomastic Sciences (Cracow, August 21-25, 1978). Vol. II, edited by K. Rymut, 63-67. Wrocław: Nakładem Uniwersytetu Jagiellońskiego.

Manova-Georgieva, Yana. 2016. "Name Choice and Symbolism In Literature - An Overview of William Thackeray's 'The Book of Snobs'.” RS Global Journals 4 (6): 29-31. https://rsglobal.pl/index.php/ws /article/view/957. 
—. 2017. "A Look into Symbolism in Literature from the Perspective of 'Vanity Fair' by William Thackeray." Ezikov svyat "Orbis Linguarum" 15 (2): 54-64.

Netsova, Milena. 2016. Система на английските фамилни имена [The System of English Family Names]. Sofia: Iztok-Zapad.

Ragussis, Michael. 1986. Acts of Naming: The Family Plot in Fiction. New York, Oxford: Oxford University Press.

Weekley, Ernest. 1914. The Romance of Names. New York: E. P. Dutton \& Company.

Withycombe, Elizabeth. 1947. The Oxford Dictionary of English Christian Names. Oxford: Oxford University Press.

Van Langendonck, Willy. 2007. Trends in Linguistics. Studies and Monographs: Theory and Typology of Proper Names. Berlin: Walter de Gruyter.

Vlahov, Sergey, and Sider Florin. 1990. Непреводимото в превода [The Untranslatable in Translation]. Sofia: Nauka i Izkustvo. 